\title{
FAKTOR PSIKOLOGIS DAN PSIKOSOSIAL YANG MEMPENGARUHI POST PARTUM BLUES DI RUANG NIFAS HIBRIDA RSU SEMBIRING
}

\author{
Irma Suryani ${ }^{1}$,Tetty Junita Purba ${ }^{2}$,Mutiara Dwi Yanti ${ }^{3}$ \\ INSTITUT KESEHATAN DELI HUSADA, Jl. Besar Delitua No 77 \\ e-mail : irmasoeryani78@gmail.com
}

\begin{abstract}
Post partum blues is a mild effective syndromic disorder that occurs at the beginning of postpartum. Signs of symptoms that arise are sad reactions, crying, irritability, anxiety, self-blame, disturbances in sleep patterns and appetite disorders. Post partum blues symptoms are a multifactorial mechanism consisting of hormonal factors, physical activity factors and psychosocial factors. This type of research is observational with cross sectional design. The population was all postpartum postpartum second day postpartum mothers in the postpartum Sembiring General Hospital Delitua sub-district in 2019 which was conducted on June 1-30, 2019. The sampling technique was done by total sampling which received 89 respondents and analyzed by chi square test significance level $p=0.05$. Independent variables are psychological and psychosocial factors and the dependent variable is post partum blues. The results of this study indicate that $66.3 \%$ of postpartum mothers experience post partum blues. From the variables obtained, each value of $p=$ $0,000$ ( $p<0.05)$, namely stress coping, self-adjustment, education and income, showed a significant relationship to the occurrence of post partum blues. The conclusions that can be drawn from this study are the psychological and psychosocial factors which most cause post partum blues are low economic factors. Therefore, to reduce the rate of occurrence of post partum blues, it is necessary to improve economic status.
\end{abstract}

Keywords: Psychological, Psychosocial, Post Partum Blues Factors.

\section{PENDAHULUAN}

Kehamilan dan persalinan merupakan suatuhal yang fisiologis yang didambakan oleh seorang ibu yang akan menjadi suatu kondisi yang membahagiakan, namun masih ada ibu yang mengalami depresi pada kehamilannya maupun pada saat nifas. Sekitar $10-20 \%$ wanita berusaha melawan gejala depresi dan seperempatnya sampai setengahnya mengalami depresi berat ketika hamil dan bersalin. Hal ini terjadi karena wanita dua kali lebih rentan mengalami depresi dibandingkan laki-laki (Yulianti, 2006).

Peran sebagai seorang ibu baru, seorang perempuan dapat merasakan hidup menjadi lebih berarti dan bermakna. Namun tidak demikian dengan sebagian perempuan yang justru merasa sedih, jengkel, lelah, ingin marah, merasa tidak berarti, serta putus asa dalam menjalani harihariawalsebagai seorang ibu. Jika hal ini dibiarkan, tentu akan berakibat buruk bagi ibu maupun bagi bayinya. Tanda dan gejala tersebut merupakan suatu kondisi yang disebut sebagai depresi pasca persalinan (Elvira, 2011).

Salah satu depresi pasca persalinan adalah post partum blues, yang merupakan tahap awal dari depresi post partum dan post partum psikosis. Ada kalanya ibu mengalami perasaan sedih yang berkaitan dengan bayinya dimana keadaan ini disebut baby blues, yang disebabkan oleh perubahan emosional dan perubahan fisik serta rasa lelah yang dialami ibu saat hamil sehingga sulit menerima kehadiran bayinya (Sari, 2014). Gejala-gejala yang timbul pada post partum blues seperti mudah tersinggung, mudah menangis, sedih, lelah, dan mengalami ketidak stabilan emosi yang disebabkan karena perubahan hormon, namun kondisi ini juga dapat dipicu oleh adanya perasaan belum siap menghadapi lahirnya bayi, dan timbulnya 
kesadaran akan meningkatnya tanggung jawab sebagai ibu (Elvira, 2011).

Post Partum Blues adalah depresi yang dialami oleh perempuan pasca persalinan pada antara hari ketujuh hingga hari keempat belas. Dari penelitian yang telah dilakukan, diketahui bahwa di negara barat depresi pasca persalinan di alami oleh lebih kurang $15-20 \%$ dari perempuan yang melahirkan, baik yang pertama kali maupun yang berikutnya. Di Malaysia diketahui bahwa ibu yang mengalami depresi pasca persalinan sebanyak 3,9\% sedangkan di Singapura angka kejadiannya hanya $1 \%$. Prevalensi post partum blues di Tanzania sebanyak $80 \%$, sementara di Asia prevalensi terjadinya post partum blues antara $25-85 \%$, sedangkan di Indonesia memiliki jumlah yang cukup tinggi dengan prevalensi 5070\% (Hidayat, 2007). Di Jakarta, Yogyakarta dan Surabaya diperoleh data bahwa angka kejadian depresi pasca persalinan sekitar $15-20 \%$ yang merupakan jumlah yang tidak sedikit, yang tidak mungkin dibiarkan begitu saja karena akan berdampak negatif terhadap ibu post partum (Elvira, 2011).

Beberapa penelitian sudah pernah dilakukan, menurut penelitian yang dilakukan oleh Fatimah Nuril Alifah pada tahun 2016 dengan judul Hubungan Faktor Psikososial Terhadap Kejadian Post Partum Blues Di Ruang Nifas RSUD dr.Abdoer Rahem Situbondo didapatkan hasil 65\% responden mengalami post partum blues. Penelitian selanjutnya di lakukan oleh Susanti Prastya Ningrum pada tahun 2017 dengan judul: Faktor-faktor psikologis yang mempengaruhi post partum blues di RSIA Malang didapatkan 46,1\% responden yang mengalami post partum blues.

Faktor penyebab terjadinya post partum blues yaitu terjadinya perubahan hormon yang terjadi pada ibu pasca salin yang mengalami perubahan tubuh ibu. Disamping perubahan fisik, hadirnya seorang bayi dapat membuat perbedaan besar bagi kehidupan seorang ibu, kelelahan mengasuh bayi. Faktor lain yang menyebabkan post partum blues yaitu faktor psikologis yang meliputi coping stress, penyesuaian diri dan dukungan sosial, dan faktor psikososialyang meliputi usia, paritas, pendidikan, status ekonomi serta pengalaman melahirkan. Penyebab tertinggi terjadinya post partum blues dikarenakan kurangnya dukungan suami dan keluarga terhadap ibu mulai dari kehamilan hingga pasca salin (Sari, 2014).

\section{METODE}

Jenis penelitian ini adalah pengamatan dengan desain penampang silang. Populasi adalah semua pasca melahirkan Postpartum hari kedua ibu pascamelahirkan di Kecamatan Postpartum Sembiring rumah sakit umum Delitua di 2019 yang dilakukan pada Juni 1-30, 2019. Teknik sampling yang digunakan adalah total sampling yaitu 89 responden dan dianalisis dengan Uji Chi Square yang bertujuan untuk mengetahui pengaruh faktor psikologis dan psikososial terhadap Post Partum Blues.

\section{HASIL DAN PEMBAHASAN}

Tabel 1 menunjukkan karakteristik responden dimana dari 89 responden di ruang nifas Hibrida RSU Sembiring ibu post partum yang berumur < 20-35 tahun sebanyak 59 orang $(66.3 \%)$ dan ibu yang berumur $>35$ tahun 30 orang $(33,7 \%)$.

Tabel 1. Karakteristik Responden

\begin{tabular}{llll}
\hline Karakteristik Responden & F & & \% \\
\hline Umur & $<20-35$ & 59 & 66,3 \\
& $>35$ & 30 & 33,7 \\
Paritas & Primipara & 52 & 58,7 \\
& Multipara & 37 & 41,6 \\
Pekerjaan & Bekerja & 32 & 36,0 \\
& Tidak Bekerja & 57 & 64,0 \\
\hline & Total & $\mathbf{8 9}$ & $\mathbf{1 0 0}$ \\
\hline
\end{tabular}

Mayoritas ibu post partum adalah primipara sebanyak 52 orang $(58,7 \%)$ dan yang multipara 37 orang $(41,6 \%)$. Ibu post partum yang bekerja sebanyak 32 orang $(36,0 \%)$, dan yang tidak bekerja 57 orang $(64,0 \%)$.

Tabel 2. Kejadian Post Partum

\begin{tabular}{lll}
\hline Post Partum Blues & F & $\mathbf{\%}$ \\
\hline Post Partum Blues & 59 & 66,3 \\
Tidak Post Partum Blues & 30 & 33,7 \\
\hline Total & $\mathbf{8 9}$ & $\mathbf{1 0 0}$ \\
\hline
\end{tabular}


Berdasarkan hasil penelitian terhadap 89 responden yang rawat inap di ruang nifas Hibrida RSU Sembiring Delitua maka didapat kejadian post partum blues yang pling dominan yaitu terjadi post partum blues sebanyak 59 Orang $(66,3 \%)$, dan yang tidak menngalami post partum blues sebanyak 30 orang (33,7\%).

Tabel 3. Faktor Coping Stres yang mempengaruhi Post Partum Blues

\begin{tabular}{lccccccc}
\hline \multicolumn{7}{c}{ Post Partum Blues } \\
\hline $\begin{array}{l}\text { Coping } \\
\text { Stres }\end{array}$ & \multicolumn{2}{c}{$\begin{array}{c}\text { Tidak Post } \\
\text { Partum Blues }\end{array}$} & $\begin{array}{c}\text { Post Partum } \\
\text { Blues }\end{array}$ & & Total \\
\cline { 2 - 8 } & $\mathrm{n}$ & $\%$ & $\mathrm{n}$ & $\%$ & $\mathrm{n}$ & $\%$ & $P$-Value \\
\cline { 2 - 8 } Ringan & 21 & 23,6 & 6 & 6,7 & 27 & 30,3 & \\
Sedang & 8 & 9,0 & 38 & 42,7 & 46 & 51,7 & 0,000 \\
Berat & 1 & 1,1 & 15 & 16,9 & 16 & 18,0 & \\
\hline Total & 30 & & 59 & & 89 & 100 & \\
\hline
\end{tabular}

Berdasarkan tabel 3. dapat dilihat responden yang mengalami stres ringan dengan kejadian tidak post partum blues sebanyak 21 orang $(23,6 \%)$, dan yang mengalami stres ringan dengan kejadian post partum blues sebanyak 6 orang $(6,7 \%)$. Responden yang mengalami stres sedang dengan kejadian tidak post partum blues sebanyak 8 Orang $(9,0 \%)$, dan yang mengalami stres sedang dengan kejadian post partum blues sebanyak 38 orang $(42,7 \%)$. Responden yang mengalami stres berat denga kejadian tidak post partum blues sebanyak 1 orang $(1,1 \%)$, dan yang mengalami stres berat dengan kejadian post partum blues sebanyak 15 orang (16,9\%).

Tabel 4. Faktor Penyesuaian Diri Yang Mempengaruhi Post Partum Blues

\begin{tabular}{|c|c|c|c|c|c|c|c|}
\hline & \multicolumn{7}{|c|}{ Post Partum Blues } \\
\hline \multirow[t]{2}{*}{$\begin{array}{l}\text { Penyesuai } \\
\text { an Diri }\end{array}$} & \multicolumn{4}{|c|}{$\begin{array}{l}\text { Tidak Post } \\
\text { Partum Blues }\end{array}$} & \multicolumn{3}{|c|}{$\begin{array}{l}\text { P.Partum } \\
\text { Blues }\end{array}$} \\
\hline & $\mathbf{n}$ & $\%$ & $\mathbf{N}$ & $\%$ & $\mathbf{n}$ & $\%$ & p- \\
\hline Menerima & 22 & 24,7 & 9 & 10,1 & 31 & 34,8 & $\begin{array}{l}0,00 \\
0\end{array}$ \\
\hline $\begin{array}{l}\text { Tidak } \\
\text { Menerima }\end{array}$ & 8 & 9,0 & 50 & 56,2 & 58 & 65,2 & \\
\hline Total & 30 & 33,7 & 59 & 66,3 & 89 & 100 & \\
\hline
\end{tabular}

Berdasarkan tabel 4. dapat dilihat bahwa responden yang menerima penyesuaian diri terhadap kejadian tidak post partum blues sebanyak 22 orang $(24,7 \%)$, dan responden yang menerima penyesuaian diri terhadap kejadian post partum blues sebanyak 9 orang $(10,1 \%)$. Responden yang tidak menerima penyesuaian diri terhadap kejadian tidak post partum blues sebanyak 8 orang $(9,0 \%)$, dan responden yang tidak menerima penyesuaian diri terhadap kejadian post partum blues sebanyak 50 orang (56,2\%).

Tabel 5. Faktor Pendidikan Yang Mempengaruhi Post Partum Blues

\begin{tabular}{|c|c|c|c|c|c|c|c|}
\hline \multicolumn{7}{|c|}{ Post Partum Blues } & \multirow[b]{2}{*}{ Nilai } \\
\hline \multirow[t]{2}{*}{ Pendidikan } & & & $P P_{L}$ & & Total & & \\
\hline & $\mathbf{n}$ & $\%$ & $\mathbf{n}$ & $\%$ & $\mathbf{n}$ & $\%$ & $p$ \\
\hline Rendah & 2 & 2,2 & 57 & 64,0 & 59 & 66,3 & 0,000 \\
\hline Tinggi & 28 & 31,5 & 2 & 2,2 & 30 & 33,7 & \\
\hline Total & 30 & 33,7 & 59 & 66,3 & 89 & 100 & \\
\hline
\end{tabular}

Berdasarkan tabel 5. dapat dilihat bahwa responden yang memilki pendidikan rendah terhadap kejadian tidak post partum blues sebanyak 2 orang $(2,2 \%)$, dan responden yang berpendidikan rendah terhadap post partum blues sebanyak 57 orang $(64,0 \%)$. Responden yang berpendidikan tinggi terhadap kejadian tidak post partum blues sebanyak 28 orang $(31,5 \%)$, dan responden yang berpendidikan tinggi dengan kejadian post partum blues sebanyak 2 orang $(2,2 \%)$.

Tabel 6. Faktor Pendapatan Yang Mempengaruhi Post Partum Blues

\section{Post Partum Blues}

\begin{tabular}{|c|c|c|c|c|c|c|c|}
\hline \multirow[t]{2}{*}{ Pendapatan } & \multicolumn{2}{|c|}{ Tidak PPB } & \multicolumn{2}{|c|}{$P P B$} & \multicolumn{2}{|c|}{ Total } & \multirow{2}{*}{$\begin{array}{l}\text { Nilai } \\
p\end{array}$} \\
\hline & $\mathbf{n}$ & $\%$ & $\mathbf{n}$ & $\%$ & $\mathbf{N}$ & $\%$ & \\
\hline $\begin{array}{l}\text { Kurang dari } \\
\text { UMR }\end{array}$ & 2 & 2,2 & 58 & 65,2 & 60 & 67,4 & 0,000 \\
\hline Diatas UMR & 28 & 31,5 & 1 & 1,1 & 29 & 32,6 & \\
\hline Total & 30 & 33.7 & 59 & 66,2 & 89 & 100 & \\
\hline
\end{tabular}

Berdasarkan tabel 6 dapat dilihat bahwa pendapatan kurang dari UMR dengan kejadian tidak post partum blues sebanyak 2 orang $(2,2 \%)$, dan pendapatan kurang dari UMR dengan kejadian post partum blues sebanyak 58 orang $(62,5 \%)$. Responden yang pendapatan diatas UMR dengan kejadian tidak post partum blues sebanyak 28 orang $(31,5 \%)$, dan responden yang pendapatan diatas UMR dengan kejadian post partum blues sebanyak 1 orang $(1,1 \%)$. 
Tabel 7. Faktor Dukungan Suami dan Keluarga Yang Mempengaruhi Post Partum Blues

\begin{tabular}{llllllll}
\hline $\begin{array}{l}\text { Dukungan } \\
\text { Suami } \\
\text { dan } \\
\text { Keluarga }\end{array}$ & $\begin{array}{l}\text { Tidak } \\
\text { Post } \\
\text { Partum } \\
\text { Blues }\end{array}$ & $\begin{array}{l}\text { Post } \\
\text { Partum } \\
\text { Blues }\end{array}$ & & Total & Nilai \\
\cline { 2 - 8 } & $\mathbf{n}$ & $\mathbf{0}$ & $\mathbf{n}$ & $\mathbf{0}$ & $\mathbf{n}$ & $\mathbf{0}$ & $\boldsymbol{P}$ \\
\cline { 2 - 8 } $\begin{array}{l}\text { Didukung } \\
\text { Tidak }\end{array}$ & $\mathbf{2 2}$ & 24,7 & 45 & 50,6 & 67 & 75,3 & 0,761 \\
Didukung & & 9,0 & 14 & 15,7 & 22 & 24,7 & \\
\hline Total & $\mathbf{3 0}$ & $\mathbf{3 3 . 7}$ & $\mathbf{5 9}$ & $\mathbf{6 6 . 3}$ & $\mathbf{8 9}$ & $\mathbf{1 0 0}$ & \\
\hline
\end{tabular}

Berdasarkan tabel 7 dapat dilihat bahwa dukungan suami dan keluarga yang didukung terhadap kejadian tidak post partum blues sebanyak 22 orang $(24,7 \%)$, dan responden yang tidak didukung dengan kejadian tidak post partum blues sebanyak 8 orang $(9,0 \%)$. Responden yang didukung terhadap kejadian post partum blues sebanyak 45 orang (50,6\%), dan responden yang tidak didukung terhadap kejadian post partum blues sebanyak 14 orang (15,7\%). Dari hasil uji Chi-square didapat nilai $p$ adalah 0,761 yang artinya bahwa tidak ada pengaruh dari dukungan suami dan keluarga yang dapat mempengaruhi terjadinya post partum blues. Dan nilai $\mathrm{RP}=1,169$ yang artinya bahwa ibu post partum yang tidak mendapatkan dukungan suami dan keluarga dapat beresiko 1,169 kali mengalami post partum blues.

Tabel 8. Faktor Status Kehamilan Yang Mempengaruhi Post Partum Blues

\begin{tabular}{|c|c|c|c|c|c|c|c|}
\hline \multicolumn{8}{|c|}{ Post Partum Blues } \\
\hline \multirow[t]{2}{*}{$\begin{array}{l}\text { Status } \\
\text { Kehamilan }\end{array}$} & \multicolumn{2}{|c|}{$\begin{array}{l}\text { Tidak } \\
\text { ppB }\end{array}$} & \multicolumn{2}{|c|}{$P P B$} & \multicolumn{2}{|c|}{ Total } & Nilai \\
\hline & $\mathbf{n}$ & $\%$ & $\mathbf{n}$ & $\%$ & $\mathbf{n}$ & $\%$ & $\boldsymbol{p}$ \\
\hline $\begin{array}{l}\text { Yang } \\
\text { Diinginkan }\end{array}$ & 22 & 24,7 & 45 & 50,6 & 67 & 75,3 & 0,761 \\
\hline $\begin{array}{l}\text { Yang Tidak } \\
\text { Diinginkan }\end{array}$ & 8 & 9,0 & 14 & 15,7 & 22 & 24,7 & \\
\hline Total & 30 & & 59 & & 89 & 100 & \\
\hline
\end{tabular}

Berdasarkan tabel 8. dapat dilihat bahwa status kehamilan yang diinginkan terhadap kejadian tidak post partum blues sebanyak 22 orang $(24,7 \%)$, dan status kehamilan yang tidak diinginkan terhadap kejadian tidak post partum blues sebanyak 8 orang (9,0\%). Responden dengan status kehamilan yang diinginkan terhadap kejadian post partum blues sebanyak 45 orang $(50,6 \%)$, dan status kehamilan yang tidak diinginkan terhadap kejadian post partum blues sebanyak 14 orang $(15,7 \%)$. Berdasarkan hasil uji chi-square didapat nilai $\mathrm{p}$ adalah 0,761 yang artinya tidak ada pengaruh status kehamilan terhadap terjadinya post partum blues. Dengan nilai $\mathrm{RP}=1,169$ yang artinya bahwa ibu post partum yang mengalami kehamilan yang tidak diinginkan akan beresiko 1,169 kali mengalami post partum blues.

\section{KarakteristikResponden}

Remaja memiliki pengetahuan yang terbatas tentang kehamilan, persalinan dan nifas dan kurangnya informasi dalam mengakses pelayanan kesehatan yang ada. Selain itu pada usia < 20 tahun juga belum cukup mencapai kematangan fisik, mental, peran dan aktifitas baru sebagai ibu dalam merawat bayi (Nirwana, 2001). Ibu primipara merupakankelompok yang sangat rentan mengalami post partum blues karena belum siap menghadapi proses kelahiran bayi sehingga sangat memungkinkan terjadinya post partum blues.

\section{Faktor Psikologis Yang Mempengaruhi Post PartumBlues}

Berdasarkan hasil uji statistik chi-square untuk faktor psikologis coping stres yang mempengaruhi post partum blues di ruang nifas Hibrida RSU Sembiring Kecamatan Delitua tahun 2019 yang telah dilakukan dengan jumlah responden 89 orang maka diperoleh hasil stres sedang sebanyak 46 orang $(51,7 \%)$, dan yang paling rendah stres berat sebanyak 16 orang $(18,0 \%)$, dengan nilai $p$ adalah $0,000<0,05$, artinya coping stres berpengaruh terhadap terjadinya post partum blues.

Hal ini sejalan dengan penelitian yang dilakukan oleh Hasjanah (2013) ibu yang mengalami post partum blues biasanya akan menngalami ketidak seimbangan dalam diri ibu yang telah melewati persalinan. Sehingga untuk menyeimbangkan dan menyesuaikan diri 
diperlukan adanya perilaku coping yang dapat membantu ibu post partum dalam kondisi seimbang.

Terdapat 2 macam bentuk koping yaitu problem focused coping (PFC) dan emotional focused coping (EFC). Safarino (1994) mengungkapkan bahwa PFC merupakan bentuk coping yang bertujuan mengurangi tuntutan dari situasi yang penuh tekanan dengan belajar keterampilan yang baru. Ibu yang menggunakan coping ini memiliki keyakinan bahwa tuntutan situasi yang penuh tekanan itu bisa berubah sementara itu, EFC mengarah pada individu berusaha untuk mengatur respon emosional dari situasi yang penuh dengan tekanan.

Berdasarkan hasil uji statistik chi-square untuk faktor psikologis penyesuaian diri yang mempengaruhi post partum blues di ruang nifas Hibrida RSU Sembiring kecamatan Delitua tahun 2019 yang telah dilakukan dengan jumlah responden 89 orang maka diperoleh hasil wanita yang tidak menerima penyesuaian diri sebanyak 58 orang $(62,5 \%)$, dan yang paling rendah adalah wanita yang menerima penyesuaian diri sebanyak 31 orang $(34,8 \%)$, dengan nilai $p$ adalah $0,000<0,05$ yang artinya penyesuain diri berpengaruh terhadap terjadinya post partum blues.

Ibu yang mengalami kehamilan pertama tentu saja perlu menyesuaikan diri dengan beberapa perubahan yang terjadi baik pada tubuhnya maupun kebiasaan-kebiasaan sebelum dan sesudah hamil dan bersalin. Perubahan yang terjadi termasuk dalam menjalankan aktifitas dan peran barunya sebagai ibu pada minggu pertama atau bulan-bulan pertama. Sebagian ibu mengalami kesulitan untuk menyesuaikan diri dengan aktifitas dan peran barunya, akan mengembangkan perasaan-perasaan tidak nyaman seperti perasaan takut, khawatir, sedih, dan merasa sendirian. Perasaan-perasaan tidak nyaman ini menjadi tanda awal terjadinya post partum blues.

Hasil uji statistik chi-square untuk faktor psikososial pendidikan yang mempengaruhi post partum blues di ruang nifas Hibrida RSU Sembiring Kecamatan Delitua tahun 2019 yang telah dilakukan dengan jumlah responden 89 orang maka diperoleh hasil pendidikan rendah sebanyak 59 orang $(66,3 \%)$, dan yang paling rendah adalah pendidikan tinggi sebanyak 30 orang $(33,7 \%)$, dengan nilai $p$ adalah $0,000<$ 0.05 , yang artinya pendidikan berpengaruh terhadap terjadinya post partum blues.

Pendidikan adalah faktor yang turut berperan terhadap kejadian post partum blues. Seorangibu yang berpendidikan tinggi dapat menghadapi tekanan sosial dan konflik peran, antara tuntutan sebagai perempuan yang memiliki dorongan untuk bekerja atau melakukan aktifitasnya di luar rumah, dengan peran mereka sebagai ibu rumah tangga dan orang tua dari anak-anak mereka.

Hasil uji statistik chi-square faktor psikososial pendapatan yang mempengaruhi post partum blues di ruang nifas Hibrida RSU Sembiring Kecamatan Delitua tahun 2019 yang telah dilakukan dengan jumlah responden 89 orang maka diperoleh hasil pendapatan kurang dari UMR dengan kejadian post partum blues sebanyak 58 orang $(62,5 \%)$. Responden yang pendapatan diatas UMR dengan kejadian post partum blues sebanyak 1 orang $(1,1 \%)$, dengan nilai $p$ adalah $0,000<0,05$ yang artinya pendapatan berhubungan dengan kejadian post partum blues.

Hasil penelitian ini sejalan dengan Ibrahim (2011) menunjukkan sebagian besar post partum blues terjadi pada responden dengan status ekonomi rendah dengan nilai $p=0,009$ yang berarti ada hubungan yang bermakna antara pendapatan dengan kejadian post partum blues.

Berdasarkan hasil uji statistik chi-square untuk faktor psikososial dukungan suami dan keluarga yang mempengaruhi post partum blues di ruang nifas Hibrida RSU Sembiring Kecamatan Delitua tahun 2019 yang telah dilakukan dengan jumlah responden 89 orang maka diperoleh hasil responden yang didukung dengan kejadian post partum blues sebanyak 45 orang $(50,6 \%)$, dan responden yang tidak didukung terhadap kejadian post partum blues sebanyak 14 orang $(15,7 \%)$, dengan nilai $p=0,761>0,05$ yang artinya tidak ada hubungan yang terkait antara dukungan 
suami dan keluarga terhadap kejadian post partum blues.

Dukungan suami dan keluarga sangat penting pada ibu masa post partum dalam menjalani perawatan dirinya dan bayinya. Dukungan suami dan keluarga yang tinggi berupa perhatian, komunikasi dan hubungan emosional yang intim, merupakan faktor yang bermakna bagi ibu post partum untuk mengurangi terjadinya gangguan psikologis.

Hasil penellitian ini tidak sesuai dengan penelitian yang dilakukan oleh Fatimah (2009) yang menyatakan bahwa ada hubungan antara dukungan suami dengan kejadian post partum blues dengan nilai $p=0,033$. Penelitian lain yang dilakukan oleh Azizah (2010) menyatakan ada hubungan dukungan suami dan keluarga terhadap kejadian post partum blues dengan nilai $p=$ 0,000 .

Sesuai dengan teori oleh Bobak (2005) bahwa dengan kehamilan yang diinginkan maka seorang ibu akan semakin siap untuk menghadapi persalina dan menjadi seorang ibu. Persiapan untuk persalinan dan menjadi ibu akan sangat menetukan apakah seseorang mengalami post partum blues atau tidak. Adanya persiapan yang baik membuat ibu post partum akan mampu menghadapi pasca persalinannya dengan baik.

Penelitian ini sejalan dengan penelitian dari Sari Priyanti (2013) yang menyatakan tidak ada hubungan status kehamilan (yang diinginkan dan yang tidak diinginkan) dengan terjadinya post partum blues dengan nilai $p=0,209$. Penelitian lain yang dilakukan oleh Yulianti dan Irawati (2013) yang menyatakan bahwa terdapat hubungan yang bermakna antara status kehamilan (yang diinginkan dan yang tidak diinginkan) dengan kejadian post partum blues dengan nilai $p=0,027$ yang berarti secara umum terdapat hubungan antara status kehamilan dan post partum blues.

\section{KESIMPULAN}

1. Faktor yang berpengaruh terhadap terjadinya post partum blues adalah coping stres, penyesuaian diri dengan tidak menerima terhadap penyesuaian diri, Pendidikandan pendapatan masing-masing memiliki nilai $p=$ 0,000 .

2. Faktor yang tidak berpengaruh terhadap terjadinya post partum blues adalah dukungan suami dan keluarga dan status kehamilan dengan nilai $p=0,761$.

\section{DAFTAR PUSTAKA}

Alifah Fatimah Nuril, 2016. Hubungan Faktor Psikososial Terhadap Kejadian Post Partum Blues, Skripsi, Universitas Airlangga.

Arfian Soffin, 2012. Baby Blues. Solo: Metagraf.

Bahiyatun, 2009. Buku Ajar Kebidanan Nifas Normal. Jakarta: EGC.

Bobak, Luadermik, Jensen, et all. 2004. Buku Ajar Keperawatan Maternitas. Jakarta: EGC.

Cunningham, G. F et all, 2006. Obstetri Williams. Edisi 21st ed, Vol.2. Jakarta: EGC.

Elvira, Sylvia, D, 2011. Depresi Pasca Persalinan. Jakarta: Fakultas Kedokteran Universitas Indonesia.

Evalina, 2018. Hubungan Konsep diri Dengan Depresi Post Partum Di Rumah Sakit Umum Sembiring Deli Tua.

Kebidanan, 2017. Teori dan Asuhanl Editor, Runjati, Syahniar Umar. Editor Penyelaras, Monica Ester. Jakarta: EGC.

Machfoedz Ircham, 2016, Metodologi Penelitian. Yogyakarta : Fitramaya.

Murtiningsih Alfin, 2012, Mengenal Baby Blues Dan Pencegahannya. Jakarta: Niaga Swadaya.

Ningrum Prasetya Susanti, 2017. Faktor-faktor Psikologis Yang Mempengaruhi Post Partum Blues. http://drive.google.com/file/d/infl2BPwus DFOEutd-sHGpF3vxbrpG/view?USP: driveesdk.

Nirwana Ade B, 2011. Psikologi Ibu Bayi Dan Anak. Jogjakarta: Nuha Medika.

Notoadmojo, S, 2012. Metodologi Penelitian Kesehatan. Jakarta: Rineka Cipta.

Nursalam, 2008. Pendidikan Dalam Keperawatan. Jakarta: Salemba Medika. 


\begin{tabular}{c|c|c}
\hline $\begin{array}{c}\text { Jurnal Penelitian Keperawatan } \\
\text { Medik }\end{array}$ & Vol. 2 No. 1 & Edition: May - October 2019 \\
\hline & $\frac{\text { http://ejournal.delihusada.ac.id/index.php/JPKM }}{\text { Revised: 08 October 2019 }}$ & Accepted: 24 October 2019 \\
\cline { 2 - 3 } Received: 03 October 2019 & & \\
\hline
\end{tabular}

Nursalam, 2008. Konsep Dan Penerapan Metodologi Penelitian Riset Keperawatan Pedoman Skripsi, Tesis Dan Instrumen Penelitian Keperawatan. Jakarta: Salemba Medika.

Rukiyah Yeyeh Ai, 2012. Asuhan Kebidanan 4 (Patologi) Bagian 2. Jakarta: CV. Trans Info Media.

Rukiyah Yeyeh Ai, 2012. Asuhan Kebidanan Nifas. Jakarta: CV. Trans Info Media.

Sari Puspita Eka, 2014. Asuhan Kebidanan Nifas. Jakarta: CV. Trans Info Media. 